\title{
ОСОБЛИВОСТІ ПЕРЕБІГУ COVID-19 У СТУДЕНТІВ МЕДИЧНОГО ФАКУЛЬТЕТУ В УМОВАХ ДИСТАНЦЙНОГО НАВЧАННЯ
}

\section{Особливості перебігу COVID-19 у студентів медичного факультету в умовах дистанційного навчання}

\section{Л. Б. Романюк}

Тернопільський національний медичний університет імені І. Я. Горбачевського МОЗ України

Резюме. Актуальність епідеміології COVID-19 не викликає сумніву, оскільки кожного дня статистика поповнюється новими даними про захворюваність. Студенти для попередження поширення інфрекції перебувають на дистанційному навчанні.

Мета дослідження - визначити відсоток студентів-медиків із коронавірусною інфрекцією упродовж минулого навчального року, визначити орактори ризику та особливості перебігу COVID-19 в амбулаторних умовах.

Матеріали і методи. Дослідження проводили методом дистанційного on-line-анкетування, результати оброблено за загальними правилами варіаційної статистики.

Результати. Встановлено, що 33,3 \% студентів II-III курсів перехворіли на COVID-19, максимальна кількість випадків припала на осінь 2020 р. (45,5 \%) та на січень-лютий 2021 р. - 27,2 \%; у половини опитаних хвороба перебігала у легкій формі; 86,4 \% - лікувались амбулаторно; провідними симптомами були гарячка, втрата нюху та смаку, головний біль та загальна втома. У 9,0 \% респондентів лабораторно підтверджена коронавірусна інсрекція перебігала безсимптомно.

Висновки. Проведене дослідження свідчить про інформативність та безпеку даного методу і дає змогу оцінити рівень та особливості захворюваності серед студентів-медиків. Зважаючи на продовження навчання у багатьох медичних закладах вищої освіти у дистанційному на змішаному режимах, небезпеку інфрікування під час тісного контакту в колі однокурсників, ми плануємо розширити та продовжувати подібні дослідження.

Ключовіслова:студенти-медики;анкетування;COVID-19; перебіг; симптоми.

\section{ВСТУП}

За даними Центру громадського здоров'я, станом на 20 лютого 2021 р. в Україні зафріксовано 6295 нових підтверджених випадків коронавірусної
Peculiarities of COVID-19 course in students of the medical faculty in the conditions of distance learning

L. B. Romanyuk

I. Horbachevsky Ternopil National Medical University e-mail: romanyuk@tdmu.edu.ua

Summary. The relevance of the epidemiology of COVID-19 is not in doubt, as every day the statistics are updated with new data on the incidence. Students are in distance learning to prevent the spread of infection.

The aim of the study - to determine the percentage of medical students who contracted a coronavirus infection during the last academic year, to determine the risk factors and COVID-19 features in an outpatient setting.

Materials and Methods. The study was conducted by remote on-line questionnaire, the results were processed according to the general rules of variation statistics.

Results. As a result of the study, it was found that $33.3 \%$ of second-third year students relapsed to COVID-19, the maximum number of cases occurred in the fall of 2020 (45.5\%) and in January-February 2021 $27.2 \%$; in half of the respondents the disease was mild; $86.4 \%$ - were treated on an outpatient basis; the leading symptoms were fever, loss of smell and taste, headache and general fatigue. In $9.0 \%$ of respondents, laboratoryconfirmed coronavirus infection was asymptomatic.

Conclusions. The study testifies to the informativeness and safety of this method and allows to assess the level and features of morbidity among medical students. Given the continuation of training in many medical schools in the distance on a mixed mode, the risk of infection during close contact with classmates, we plan to expand and continue such research.

Key words: medical students; questionnaire; COVID-19; course; symptoms.

хвороби COVID-19 (з них дітей - 429, медпрацівників - 223). Кількість активних хворих - 130406 осіб. У закладах вищої освіти (ЗВО) взаємодія людей відбувається досить активно. Території цих закла- 
дів заповнені навчальними корпусами і гуртожитками, де студенти контактують між собою. ЗВО проводять безліч заходів для студентства та викладачів. Існує багато можливостей для поширення респіраторних захворювань, зокрема коронавірусної інфрекції COVID-19, викликаної вірусом SARS-CoV-2 [1, 2].

Виходячи 3 цих обставин, постановою Головного державного санітарного лікаря України від 22.08.2020 № 50 затверджено Протиепідемічні заходи у закладах освіти на період карантину у зв'язку з поширенням коронавірусної хвороби. Також уряд продовжив дію загальнонаціонального карантину з обмеженнями «помаранчевої» зони до 28 лютого 2021 р. Навчаючись у дистанційному режимі, педагогічні колективи медичних ЗВО проводять спілкування зі студентами та персоналом 3 питань профрілактики респіраторних захворювань за допомогою електронних листів, веб-сайтів, плакатів, соціальних мереж і текстових повідомлень.

Доведено, що вірус SARS-CoV-2 має надзвичайно високу тропність до трансмембранного клітинного рецептора - білка ACE2, який займає до 25 \% структури клітинної мембрани епітеліальних клітин, перш за все в альвеолярних. Досить великими є і вікові відмінності наявності та концентрації цього білка на поверхні клітин, встановлено, що його концентрація мінімальна у дітей молодшого віку і поступово підвищується, досягаючи максимуму в старшому віці 14-19 років. Це вірогідно і пояснює низьку захворюваність дітей, а у разі виникнення хвороби вона здебільшого має легкий неускладнений перебіг і більш тяжкий її перебіг у осіб старшого віку [2]. Надзвичайно багато літературних джерел засвідчують, що тяжкість перебігу коронавірусної інорекції посилюється 3 віком і є багато досліджень 3 клінічної симптоматики COVID-19 у стаціонарних хворих, однак зміни, що виникають у пацієнтів на амбулаторному лікуванні, вивчені недостатньо [2, 4].

Метою дослідження було визначити відсоток студентів-медиків із коронавірусною інфрекцією упродовж минулого навчального року, визначити фрактори ризику та особливості перебігу COVID-19 в амбулаторних умовах.

\section{МАТЕРІАЛИ I МЕТОДИ}

Під час дослідження було опрацьовано 66 студентських анкет. В анкетуванні взяли участь студенти II та III курсів медичного фракультету. Їм запропоновано дати відповіді на такі запитання:

- Чи хворіли Ви в період з лютого 2020 р. до лютого 2021 р. на COVID-19 (діагноз повинен бути підтверджений ПЛР чи ІФА)?

- Якщо хворіли, то вкажіть в якому місяці, скільки днів тривала хвороба, лікувались амбулаторно чи в умовах стаціонару?
- Чи проходили Ви дослідження на наявність антитіл проти COVID-19 після перенесеної хвороби?

- Чи хворіли на COVID-19 ваші близькі родичі, з якими Ви разом проживаєте?

Крім того, в анкету були внесені питання стосовно тяжкості перебігу коронавірусної інфекції та провідних симптомів, що мали місце під час хвороби, при чому перелік останніх не був вказаний у анкеті, а надана можливість респондентам самим назвати симптоми, котрі у них відмічались при СОVID-19.

При виборі питань, для складання анкети ми керувались засадами анонімності та даними про виникнення та перебіг коронавірусної інфекції у осіб молодого віку. Результати дослідження оброблені за загальними правилами варіаційної статистики.

\section{РЕЗУЛЬТАТИ Й ОБГОВОРЕННЯ}

Опитаний контингент склали студенти у віці від 18 до 21 року, серед них вагомо переважали особи жіночої статі - 69,7 \%, відповідно чоловіки склали 30,3 \%. Такі показники можуть бути зумовлені гендерними особливостями на медичних факультетах вітчизняних 3ВО, оскільки профресію лікаря традиційно частіше вибирають жінки. Тих, хто перенесли COVID-19, виявилось 22 (33,3 \%). Серед перехворілих дівчат було вдвічі більше, ніж хлопців (15 68,2 та 31,8 \%). Такі дані не відповідають результатам офріційної статистики, котрі вказують на відсутність гендерних особливостей при виникненні COVID-19, хоча на результати міг суттєво вплинути склад респондентів [3-5]. Перебіг коронавірусної інфекції у 86,4 \% опитаних був легкий, оскільки вони перебували на амбулаторному лікуванні й лише у 3-х осіб (13,6 \%) - середньої тяжкості, і вони ж приймали антибіотики. Опитані респонденти, які перебували на амбулаторному лікуванні, отримували лише симптоматичну терапію. Результати помісячного аналізу захворюваності студентів виявив максимальну кількість випадків захворювання у жовтні 2020 р. - 27,3 \%, у вересні, листопаді та грудні кількість хворих була суттєво нижчою, відповідно - 9,1; 13,6 та 9,1 \%. Кількість випадків COVID-19 за три місяці літа (3 червня по серпень) становила загалом 13,6 \%, що свідчить про значне зменшення захворюваності влітку. Початок 2021 р. ознаменувався підвищенням захворюваності, зокрема у січні - 13,6 \% та за 20 днів лютого - 13,6 \% опитаних, що може бути підтвердженням настання наступної хвилі епідемічного поширення коронавірусної хвороби.

У всіх опитаних, які перехворіли на COVID-19, діагноз був підтверджений методом ПЛР (полімеразно-ланцюгової реакції). Тривалість клінічних симптомів варіювала від 5-ти днів (18,2 \%) до 2-х тижнів - 31,8 \%. Однак в основному видужання на- 
стала впродовж 7-10 днів (50,0 \%). Дослідження на наявність антитіл після перенесеного захворювання проводилось у близько половини респондентів - 45,5\%.

Клінічними симптомами хвороби, за визначенням BOO3, найчастіше відзначають: гарячку, слабкість і сухий кашель, біль при ковтанні, чханні; риніт; біль голови; прояви гіпоксії; біль у м'язах. До основних клінічних критеріїв COVID-19 належать кашель і задишка чи утруднене дихання. Також, як правило, характерні гарячка, озноб, тремор, біль у м'язах, відчуття розбитості в усьому тілі. У частини пацієнтів можлива втрата нюху та смаку (аносмія та дисгевзія) $[4,5]$. Крім того, хворі можуть скаржитися на закладеність носа чи ринорею, кон'юнктивіт, шлунково-кишкові розлади - відсутність апетиту, зрідка на нудоту, блювання, пронос. Серед інших симптомів - біль у горлі, грудях, дезорієнтація, запаморочення, біль голови, кровохаркання, шкірні прояви. У більшості людей (80 \%) цих симптомів немає, або проявляються у легкій формі й не потребують лікування, алепотребуютьдіагностування і застосування стосовно них протиепідемічних заходів [3]. Однак диференційна діагностика коронавірусної інфекції неможлива лише на основі клінічних симптомів.

Наші респонденти найчастіше відмічали підвищення температури - 16 (72,3 \%), втрату нюху і смаку - 12 (54,5 \%). Значно рідше зустрічались головний біль та загальна втома - по 7 (31,8 \%) випадків. На біль у горлі та в ділянці грудної клітки були скарги у 22,7 \% студентів, які хворіли на COVID-19. Біль у м'язах турбував 18,1 \% осіб, з такою ж частотою опитані відмічали наявність кашлю. У 2 (9,0 \%) студентів лабораторно підтверджений діагноз коронавірусної інфекції, що перебігав безсимптомно. Досить багато літературних даних свідчать про те, що оцінити поширеність безсимптомних випадків у популяції досить складно, однак у Китаї про досимптомне інфікування повідомлялося на рівні 12,6 \% випадків [6]. Дещо менший відсоток безсимптомного перебігу в студентів-медиків може бути зумовлений певною настороженістю їх стосовно розвитку коронавірусної інорекції та більш ретельним ставленням до свого здоров'я.

Асоціюють виникнення захворювання із хворобою близьких родичів 10 (45,5 \%) опитаних, у решти, в колі родини, випадків коронавірусної інорекції не відмічалось, що підтверджує високий ризик зараження при недотриманні правил карантину та самоізоляції під час пандемії.

\section{вИСновкИ}

Проведене дослідження дає підстави стверджувати наступне:

- кожен третій студент-медик II-III курсів (33,3 \%), який перебував на дистанційному навчанні в період з лютого 2020 р. до лютого 2021 р. 3 коронавірусною інфекцією;

- максимальна кількість випадків припала на осінь 2020 р. (45,5 \%) та на січень-лютий 2021 р. 27,2 \%; у половини опитаних хвороба перебігала у легкій фрормі та тривала до 10 днів; 86,4% - лікувались амбулаторно, без прийому антибактеріальних засобів;

- дослідження на наявність антитіл після перенесеного захворювання проводилось у близько половини респондентів - 45,5\%;

- провідними симптомами, які відмічали студенти-медики, були гарячка, втрата нюху та смаку, головний біль та загальна втома. У 9,0 \% респондентів лабораторно підтверджена коронавірусна інфекція перебігала безсимптомно;

- асоціюють виникнення захворювання із хворобою близьких родичів - 45,5 \% опитаних.

Зважаючи на продовження навчання у багатьох медичних ВНЗ у дистанційному на змішаному режимах, небезпеку іноікування під час тісного контакту в колі однокурсників та по дорозі на заняття і назад та очевидну інорормативність даного методу, ми плануємо розширити питання, котрі будуть включені в анкети, та продовжувати подібні дослідження.

\section{СПИСОК ЛІТЕРАТУРИ}

1. Worldometers: COVID-19 Coronavirus pandemic. Last updated: 21.05.2020. [Електроннийресурс]. Accessmode: ttps://www.worldometers.info/coronavirus/

2. Комісаренко С. Світова коронавірусна криза / С. Комісаренко. - К. : ЛАТ\&К, 2020. - 120 с.

3. COVID-19: епідеміологія, клініка, діагностика, лікування та профрілактика / М. А. Андрейчин, Н. А. Ничик, Н. Г. Завіднюк [та ін.] // Інфрекційні хвороби. - 2020. - № 2 (100) - C. 41-55.

4. The epidemiology and clinical nformation about
COVID-19 / H. Ge, X. Wang, X. Yuan [et al.] // Eur. J. Clin. Microbiol. Infect. Dis. - 2020. - Vol. 14. - P. 1-9.

5. World Health Organization. Coronavirus disease 2019 (COVID-19) situation report - 47. - 2020. - Access mode : https://www.who.int/docs/default-source/coronaviruse/ situation-reports/20200307-sitrep-47-covid-19

6. Genomic characterization of the 2019 novel humanpathogenic coronavirus isolated from a patient with atypical pneumonia after visiting Wuhan / J. F.-W. Chan, K.-H. Kok, Z. Zhu [et al.] // Emerging Microbes \& Infections. - 2020. Vol. 9 (1). - P. 221-236.
ISSN 2706-6282(print) ISSN 2706-6290(online)
Вісник медичних і біологічних досліджень Bulletin of Medical and Biological Research
$1(7), 2021$ 


\section{REFERENCES}

1. Worldometers: COVID-19 Coronavirus pandemic. Last updated: 21.05.2020. [Electronic resource]. Available from: ttps: //www.worldometers.info/coronavirus/.

2. Komisarenko S. World coronavirus crisis. [Світова коронавірусна криза] Kyiv: LAT \& K; 2020. Ukrainian.

3. Andreychyn MA, Nychyk NA, Zavidniuk $\mathrm{NH}$. [COVID-19: epidemiology, clinic, diagnosis, treatment and prevention COVID-19]. Infekts khvorob. 2020;2(100): 4155. Ukrainian.
4. Ge H, Wang X, Yuan X. The epidemiology and clinical information about COVID-19. Eur J Clin Microbiol Infect Dis. 2020;14: 1-9.

5. World Health Organization. Coronavirus disease 2019 (COVID-19) situation report. 2020. Available from: https://www.who.int/docs/default-source/coronaviruse/ situation-reports/20200307-sitrep-47-covid- 19.

6. Chan JF-W, Kok K-H, \& Zhu Z. Genomic characterization of the 2019 novel human-pathogenic coronavirus isolated from a patient with atypical pneumonia after visiting Wuhan. Emerging Microbes \& Infections. 2020;9(1): 221-36. 